\title{
The Influence of Royal Institution Factor and Patriotism in Youth National Indexes of Malaysia
}

\author{
Samsudin Wahab \\ Institute of Malay Thoughts and Leadership, Universiti Teknologi MARA, 40450 Shah Alam Selangor
}

\begin{abstract}
The concern in our society today is to strengthening of identity amongst the youth. This concern is due to the characters of youth who is more curious and love to try new things, hence easily misled. The present youth is our hope for the future to govern our country. This paper studies the strength level of identity amongst youth in Malaysian selective public and private higher educational institutions. The identity components measured in this study are royal institution acceptance and patriotism contribution towards national indices in Malaysia. The manifestation of each component was analyzed via knowledge, behavior, emotion, value, and belief. This study was designed to utilize a quantitative approach with survey method. A survey questionnaire was constructed as a research instrument to collect data for this study, and an identity measurement tool was also developed by this group of researchers. The participants are 456 male and 603 female students from sixth selective higher institution with different years and streams of studies as well as ethnics. The study found that the mean for patriotism 4.16, royal institution (4.62), which make the indexes encourage able in Malaysia. In addition, there was a significant difference between ethnics $(p<0.05)$. In conclusion, the strength level of identity found by this study is alarming.
\end{abstract}

\section{Indexing terms/Keywords}

Patriotism, National Identity, Royal Institution, Young Generation.

\section{Academic Discipline And Sub-Disciplines}

Sociology; Cultural Studies

\section{SUBJECT CLASSIFICATION}

Patriotism, Thought and Leadership

\section{TYPE (METHOD/APPROACH)}

Correlational Study

\section{Council for Innovative Research}

Peer Review Research Publishing System

Journal of Social Science Research

Vol.4, No.2

editor@cirworld.com

www.cirworld.com, member.cirworld.com 


\section{INTRODUCTION}

Abraham Lincoln defined patriotism as "the devotion not only to country, but also to its principles, in our case, means the principles set down in 1776". Patriotism in its basic form is "love of country" (Primoratz, 2002). In the era of globalization the demand for tolerance the debate brings to question the motivation of the patriot and how this motivation impacts a country's ability to successfully operate in global society. There is an unanswered question in our mind, what is the impact of globalization toward patriotism among teenagers? Patriotism is a challenge for many. With the diversity in the country, political party has come out with many ideas and policy, opposition continuously challenge the government. This scenario has challenge the government in establishing harmonize in society.

The intertwined issues of Malaysian national identity and patriotism are not just matter for idle contemplation: divergent approaches to these controversial topics have shaped aspects of Malaysian lives ranging from the government's official immigration policies to the everyday experiences of Malaysia abroad, from Malaysia's position in the international community to Malaysian history lessons. The government policies and country regulation on outsourcing a man power from neighboring countries has invite a new cultural influence and interrupt a local culture and way of life. The current policies with a low enforcement on immigration act allow easy entry policy for foreigners to work and further their study in Malaysia.

For historical reasons, Malaysia offers unique nationality with a multi-racial of society since 1957 when it foam own government. In a global world with the development of culture, freedom of life, human rights and fairness have influence the nation new ways of thinking and perception towards national identity among generation Y. More specifically, the study aims to determine three variables as the dimension for national indices measurement in Malaysia. By the way ascertain whether the predictions of social identity theory (SIT:Tajfel, 1974; Tajfel \& Turner, 1979) seem to be supported. According to SIT, people maintain positive, self-enhancing identities as members of an in-group by comparing themselves favorably to an out-group.

According to SIT, people maintain positive, self-enhancing identities as members of an ingroup by comparing themselves favorably to an outgroup. The "ingroup" refers to a group of people perceived to share one's category membership (e.g. female) or social identity (e.g. Stanford student). Tajfel (1978) frames SIT as a conflict theory: social groups compete for symbolic and material resources, striving to preserve the "evaluative superiority of the

In-group at all costs" (Hogg \& Abrams, 76). SIT requires four conditions (Tajfel, 1974), which national identity satisfies. First, classification of the social world occurs based on various attributes (e.g. nationality), which often contain an implicit value dimension (good-bad). Second, individuals ascertain the categories that correspond to their own attributes (e.g. speaking Bahasa) and assign themselves to those groups. Third, social comparisons arise between the in-group and the out-group (e.g. Malay, Chinese and India). Fourth, group members affirm their own identities through these negative out-group comparisons. In this markedly relational theory, the individual's reference group is not the self but the out-group, leading some to contend that "there is no 'we,' no collective identity, without demarcation from 'others," and that "attitudes towards others should be seen as a component of the national identity itself" (Blank, Schmidt, \& We s t I e ,2001, 10).

This question-is it possible to be "pro-us" without being "anti-them?" corresponds to a distinction drawn between patriotism and nationalism. This conception posits a continuum of national identification, ranging from national consciousness (or awareness of national membership) to jingoistic nationalism, with patriotism somewhere in the middle (Blank et al.,2001). In simplified terms, both patriotism and nationalism involve positive affective ties to the nation, but only the latter entails the derogation of other nations and nationals. Moreover, empirical measures of patriotism and nationalism have proved separable or independent, and only the latter typically correlates with xenophobia (Blank et al., 2001). Such findings have led some researchers to conclude that, contrary to SIT, a positive and self-affirming patriotism exists independently from nationalismmand is not linked to outgroup derogation (Blank et al, 2001; Kosterman \& Feshbach, 1989; Müller- Peters, 1998).

In light of German history, this distinction between patriotism and nationalism makes German national identity intriguing and deeply problematic. Although nationalism, especially in its extreme forms, may meet with criticism in most sociopolitical contexts, many Germans perceive a strong national and international norm against any expression of German patriotism. In the wake of two world wars and the Holocaust, a threefold stigma against German nationalism as militaristic, extremist, and ethnocentric has developed. While taboos against nationalism do not necessarily proscribe patriotism, recent controversies reveal that many Germans blur this distinction. In fact, a prominent politician's March 2001 comment that he was "proud to be German" drew massive criticism and ignited a debate that stretched on for months and focused national attention on German patriotism (Brüning, Krumrey, Opitz, \& Stock, 2001).

This study explores the psychological consequences of attempting to positively identify oneself as a Malaysia national despite these stigmas against Malaysia nationalism and patriotism. Several possible reactions to this dilemma were hypothesized. A Malaysian individual could choose to reject the negative stereotypes and espouse patriotism or even nationalism regardless; to abandon a holistic patriotism and focus instead on specific aspects of Malaysia that merit pride; to dissociate from a primary identification as Malaysia in favor of a local, regional, continental, or global identity; to dismiss patriotism as inherently meaningless, absurd, or even inappropriate; or to accept the negative stereotypes of Malaysia and experience national identity as a source of shame or guilt. These options may not be mutually exclusive, although some combinations, for instance national pride with national shame, would likely indicate deep-seated conflict or ambivalence. 
Challenges to SIT would arise if individuals reported positive attachments to their Malaysian identity with no out-group derogation.

\section{Method}

\section{Design}

In an interregional, intergenerational study made possible by a National Civics Bureau, 1060 participants from sixth universities completed a brief questionnaire on Malaysia national identity indices. The demographics variables were (gender, age, university, sponsorship, race, and program registered), while the three primary dependent variables which are patriotism, language and social interaction measures were based on the agreement with the statements.

\section{Population and Sampling}

Table1: Selection of Students from Population

\begin{tabular}{ll}
\hline UM & Frequency \\
\hline USIM & 192 \\
\hline UiTM & 125 \\
\hline Lim Kok Wing & 201 \\
\hline MMU & 189 \\
\hline MSU & 159 \\
\hline Total & 194 \\
\hline
\end{tabular}

The method of sampluing is stratified sampling whereby the numbers of respondents for each universities are based on the ratio of Malaysian population in term of Malays, China and India. The estimated ratio of Malaysian is $70 \%$ Malays, $20 \%$ Chinese and $10 \%$ Indian.

Table 2: Distribution of Respondents According to Race

\begin{tabular}{lll} 
& Frequency & Percent \\
Melayu & 725 & 68.4 \\
\hline Cina & 227 & 21.4 \\
\hline India & 71 & 6.7 \\
\hline Lain-lain & 37 & 3.5 \\
\hline Total & 1060 & 100.0 \\
\hline
\end{tabular}

\section{Results and Finding}

Validation and Reliability Test 
Table 3: Reliability Test Result

\begin{tabular}{lllll}
\hline $\begin{array}{l}\text { Variables } \\
\text { Patriotism }\end{array}$ & $\begin{array}{l}\text { No Of Items } \\
12\end{array}$ & $\begin{array}{l}\text { Cronbach's Alpha } \\
0.769\end{array}$ & $\begin{array}{l}\text { Variance } \\
72.891\end{array}$ & $\begin{array}{l}\text { Std. Deviation } \\
8.537\end{array}$ \\
\hline Language & 6 & 0.830 & 29.616 & 5.44202 \\
Social Interaction & 5 & 0.675 & 23.231 & 4.81982 \\
\hline
\end{tabular}

The data reveal that the items for this study are reliable for patriotism, language and social interaction. According to Palent (1970), the alpha value data that above 0.6 is consider reliable and valid for conceptual measurement.

Race and National Identity Indices

Table 4: Mean Analysis between Races

\begin{tabular}{|c|c|c|c|c|}
\hline \multicolumn{2}{|c|}{ Race } & \multicolumn{2}{|r|}{$\begin{array}{c}\text { Royal } \\
\text { institutio }\end{array}$} & \multirow[b]{2}{*}{ indices } \\
\hline & & patriotism & n & \\
\hline \multirow{3}{*}{ Melayu } & Mean & 4.3422 & 4.5064 & 4.42 \\
\hline & $\mathrm{N}$ & 724 & 724 & 724 \\
\hline & Std. Deviation & .57528 & .98234 & .48835 \\
\hline \multirow[t]{3}{*}{ Cina } & Mean & 3.6476 & 3.6062 & 3.62 \\
\hline & $\mathrm{N}$ & 227 & 227 & 227 \\
\hline & Std. Deviation & .77752 & 1.00148 & .85481 \\
\hline \multirow[t]{3}{*}{ India } & Mean & 4.1491 & 3.9803 & 4.06 \\
\hline & $\mathrm{N}$ & 71 & 71 & 71 \\
\hline & Std. Deviation & .90730 & .90595 & .66269 \\
\hline \multirow{3}{*}{$\begin{array}{l}\text { Lain- } \\
\text { lain }\end{array}$} & Mean & 4.0141 & 4.1568 & 4.08 \\
\hline & $\mathrm{N}$ & 37 & 37 & 37 \\
\hline & Std. Deviation & .67281 & .75002 & .61957 \\
\hline \multirow[t]{3}{*}{ Total } & Mean & 4.1695 & 4.2662 & 4.0971 \\
\hline & $\mathrm{N}$ & 1060 & 1060 & 1060 \\
\hline & Std. Deviation & .71051 & 1.04166 & .67200 \\
\hline
\end{tabular}

Roughly overall means score shows a moderate value which are 4.16 for patriotism, 4.26 for Royal Institution acceptance. The result shows that royal institution acceptence scores higher followed by patriotism between the group ethnic. In term of national indices, it was found that Malay's respondent scores higher mean value compare to Chinese and Indians (Malays 4.42; Chinese 3.62 and Indians 4.09).

Table 5: Independent T- Test Analysis Result between Malay and Chinese Ethnic

\begin{tabular}{|c|c|c|c|c|c|c|c|}
\hline & \multirow[b]{2}{*}{$\mathrm{F}$} & \multirow[b]{2}{*}{ Sig. } & \multirow[b]{2}{*}{$\mathrm{t}$} & \multirow[b]{2}{*}{ df } & \multirow[b]{2}{*}{ Sig. (2-tailed) } & \multicolumn{2}{|c|}{$95 \%$ Confidence Interval of the Difference } \\
\hline & & & & & & Lower & Upper \\
\hline \multirow{2}{*}{${ }_{\mathrm{P}}^{\text {mean_- }}$} & 39.351 & .000 & 14.509 & 949 & .000 & .60068 & .78858 \\
\hline & & & 12.435 & 307.408 & .000 & .58471 & .80454 \\
\hline \multirow[t]{2}{*}{ mean_L } & $\begin{array}{l}113.42 \\
8 \\
\end{array}$ & .000 & 21.825 & 949 & .000 & 1.12902 & 1.35213 \\
\hline & & & 16.672 & 274.432 & .000 & 1.09409 & 1.38706 \\
\hline \multirow{2}{*}{$\begin{array}{l}\text { mean_ } \\
\text { Sl }\end{array}$} & 69.193 & .000 & 6.913 & 949 & .000 & .36364 & .65198 \\
\hline & & & 4.876 & 257.682 & .000 & .30273 & .71289 \\
\hline
\end{tabular}

By comparing the score for the two group of ethnic, there is a significant difference between Malay and Chinese ethnic (Table 5). Both dimensions show a significant difference between this two ethnic, the $p$ value is below 0.00 which is below 0.05. According to Palant (2003), that $p$ value below 0.05 means there is a significant difference between the two group comparisons.

Table 6: Independent T- Test Analysis Result between Malay and Indian Ethnic 


\begin{tabular}{|c|c|c|c|c|c|c|c|}
\hline & $\mathrm{F}$ & Sig. & $t$ & $\mathrm{df}$ & $\begin{array}{l}\text { Sig. } \\
\text { tailed) }\end{array}$ & $\begin{array}{l}\text { 95\% Confidence } \\
\text { (2- Difference } \\
\text { Lower }\end{array}$ & $\begin{array}{l}\text { Interval of the } \\
\text { Upper }\end{array}$ \\
\hline \multirow[t]{2}{*}{ mean_P } & 25.135 & .000 & 2.538 & 793 & .011 & .04378 & .34251 \\
\hline & & & 1.759 & 75.617 & .083 & -.02552 & .41181 \\
\hline \multirow[t]{2}{*}{ mean_L } & 21.828 & .000 & 7.674 & 793 & .000 & .45379 & .76575 \\
\hline & & & 5.863 & 77.239 & .000 & .40267 & .81687 \\
\hline \multirow[t]{2}{*}{ mean_IS } & 6.403 & .012 & .558 & 793 & .577 & -.12411 & .22281 \\
\hline & & & .554 & 84.010 & .581 & .04935 & .08915 \\
\hline
\end{tabular}

By comparing the mean score between Malay and Indian group of ethnic, there is a significant difference between them (Table 6). Both dimensions show a significant difference between this two ethnic, the $p$ value is below 0.00 which is below 0.05. According to Palant (2003), that p value below 0.05 means there is a significant difference between the two group comparisons.

\section{CONCLUSION AND RECOMMENDATION}

Strong effects for ethnic emerged on three of the three primary dimension measures of ways in which Malaysians relate to their national identity. Hence, royal institution acceptance is a main contributors dimension in measuring the national indices among the teenagers. The high difference in means score between the ethnic group contribute to a significant difference in term of national indices between the three ethnic group in Malaysia. There are some factors or dimension might contribute to these indices such as new government policy regarding to national integrity, team spirit and so fault.

The finding shows that the sense of nationality and loyalty towards country is very important for the nation especially in developed country. The positive attitude and perception towards government policies is compulsory because it is the pillars of succession in policy implementation. The government needs the support from society. Therefore it is important for our government to enhance and enrich the national indices among society especially for the younger group. They are the future leaders of our nation and at the same time they are customers for government.

\section{ACKNOWLEDGEMENT}

This research paper is sponsored by Research Management Institute (RMI), University Technology MARA Malaysia. Special thanks to the budgeting committee, without the research fund we have a problem in completing the research.

\section{REFERENCES}

[1] Igor Primoratz, ed., Patriotism (Amherst, New York: Humanity Books, 2002), 102.

[2] Palant, J. (2001). SPSS survival manual: A step by step guide to data analysis using SPSS for Windows 9 Version 10). Chicago, Illinois: SPSS ins.

[3] Tajfel, H. (1974). Social identity and intergroup behaviour. Social Science Information, 13, 65-93.

[4] Tajfel, H. (1978). Differentiation Between Social Groups. Academic Press, London.

[5] Tajfel, H., \& Turner, J. (1979). An integrative theory of intergroup conflict. In G. W.Austin \& S. Worchel (Eds.), Advances in Experimental Social Psychology, 21 (pp. 33-47). Monterey: Wadsworth.

[6] Hogg, M. A., \& Abrams, D. (1988). Social identifications: A social psychology of intergroup relations and group processes. London: Routledge.

[7] Blank, T., Schmidt, P., \& Westle, B. (2001). "Patriotism"-A contradiction, a possibility, or an empirical reality? Paper presented at the ECPR Workshop 26 "National Identity in Europe," in Grenoble, France.

[8] Kosterman, R., \& Feshbach, S. (1989). Towards a measure of patriotic and nationalistic attitudes. Political Psychology, $10,257-274$.

[9] Müller-Peters, A. (1998). The significance of national pride and national identity to the attitude toward the single European currency: A Europe-wide comparison. Journal of Economic Psychology, 19, 701-719.

[10] Brüning, N., Krumrey, H., Opitz, O., \& Stock W. (2001) “Schwarz-Rot-Stolz.” Focus, 13. 


\section{Author' biography with Photo}

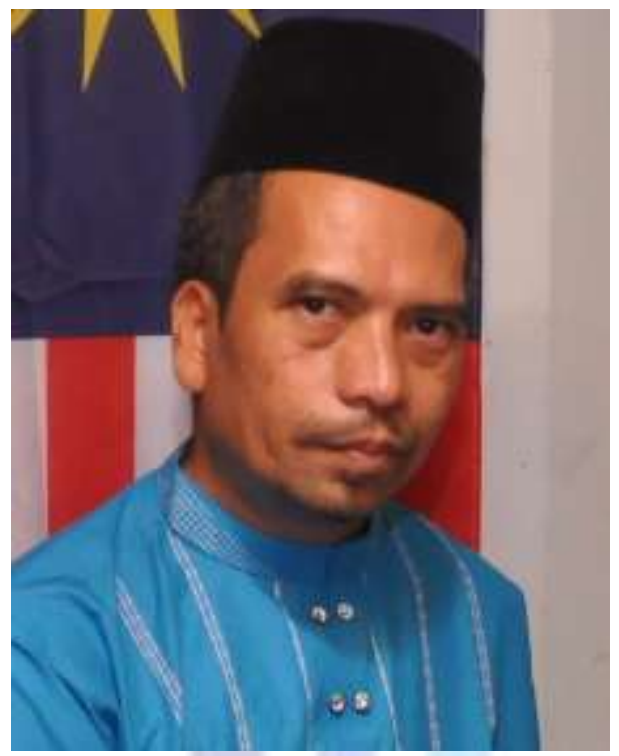

Samsudin Wahab

Doctor of Philosophy in Management, A FELLOW in Institute of Malay Thought and Leadership, Universiti Teknologi MARA Shah Alam Selangor, Malaysia. Authors more than 20 books in the area of Event Management, Office Administration, Secretarial Study, Customer Service, Customer Relationship Management, Society and Leadership.

Phone: $+603-55225170$

Hand Phone: +60193467876

Email: samsudinw@puncakalam.uitm.edu.my 